S. Kerli ${ }^{1}$, H. Eskalen ${ }^{2,3}$

\title{
Synthesis of Titanium Oxide thin Films by Spray Pyrolysis Method and its Photocatalytic Activity for Degradation of Dyes and Ciprofloxacin
}

\author{
${ }^{I}$ Department of Energy Systems Engineering, Kahramanmaras Ístiklal University, Kahramanmaras, Turkey, \\ suleymankerli@yahoo.com; \\ ${ }^{2}$ Vocational School of Health Services, Department of Medical Services and Techniques, Opticianry Program, Kahramanmaraş \\ Sütçü İmam University, Kahramanmaraş, Turkey; \\ ${ }^{3}$ Physics Department, Kahramanmaraş Sütçü Imam University, Kahramanmaraş, Turkey
}

\begin{abstract}
Titanium oxide $\left(\mathrm{TiO}_{2}\right)$ thin film was obtained using the spray pyrolysis method. The structural properties of the obtained thin film were examined by X-ray diffraction (XRD) and it was found that it had a tetragonal structure. The morphological features were examined with scanning electron microscopy (SEM). In addition, the optical properties of the film were examined and the bandgap energy was calculated. Photocatalytic properties of $\mathrm{TiO}_{2}$ thin film on different dyestuff and antibiotic were investigated. Methyl blue and malachite green were used in the dye degradation test of the thin film. In particular, it was found to have a high degradation of $86 \%$ after 100 minutes on malachite green. Moreover, the degradation on ciprofloxacin after 90 minutes was found as $93 \%$. The reusability ciprofloxacin antibiotic was investigated and it was found that synthesized $\mathrm{TiO}_{2}$ thin film has excellent stability and reusability.
\end{abstract}

Keywords: $\mathrm{TiO}_{2}$, methyl blue, malachite green, ciprofloxacin.

Received 21 August 2020; Accepted 15 September 2020.

\section{Introduction}

Environmental pollution has now become a critical problem that treat the quality of human life. As a result of the radical change of laws and regulations on the prevention and control of environmental pollutants, the issue of handling organic pollutants has become the focus of interest by the relevant enterprises and industry [1-2]. Some of the contaminants in the water are organic compounds containing dyes and antibiotic residues. It is known that some wastewaters that originated from dyes contaminate freshwater sources and land. Indeed, these also have a carcinogenic effect [3]. The chemical compounds with antibacterial properties, also known as antibiotics, are one of the most used pharmaceuticals for curing humans and animal diseases [4-5]. Ciprofloxacin (CIP) is a broad spectrum second generation fluoroquinolone antibiotics and play a critical role for treatment of diseases like pharyngitis, sinusitis and bronchitis [6], but pharmaceutical manufacturing, hospitals and excretion from human are the three common contamination ways of the CIP [4,7-8]. So, it essential to eliminate CIP from aqueous solutions.

In recent years, the photocatalytic performance of some alloys [9-10] and semiconductors [11-14] have attracted the intense attention of scientists. Titanium dioxide $\left(\mathrm{TiO}_{2}\right)$ is semiconductor powders and has a remarkable band gap and it has three different kinds of crystalline structure anatase, rutile and brookite [15-16]. It has been used as an excellent photocatalyst material due to nontoxicity, low cost, chemical stability, light resistance, high refractive index and photoinduced performance [2,17-19]. Many different methods are utilized to synthesized $\mathrm{TiO}_{2}$ thin films such as chemical vapor deposition, pulsed laser deposition, chemical bath deposition, sol-gel method, spray pyrolysis [20-21]. 
Among these methods, spray pyrolysis methods is the easiest, low-cost techniques and it is remarkably suitable for relatively large surface area coating.

In the present study, the $\mathrm{TiO}_{2}$ thin film on glass substrate was synthesized by spray pyrolysis method. In the synthesizing process, titanium chloride was used. The structural morphologic and optical properties of the synthesized thin film were examined. The main goal of this study investigates photocatalytic degradation performance of the prepared thin film by degradation ciprofloxacin antibiotic and two different dyes including malachite green and methyl blue dye in aqueous solution under solar light simulator. Moreover, the recycling performance of the thin film is also studied.

\section{Experimental}

Titanium oxide film was synthesized by using the spray pyrolysis technique on a glass substrate $(26 \times 76$ $\mathrm{mm})$. Titanium chloride $\left(\mathrm{TiCl}_{4}\right.$, Merck) chemical was used to prepare a thin film. Titanium chloride $(0.6 \mathrm{ml})$ was dissolved in $40 \mathrm{ml}$ of purified water. After then, $5 \mathrm{ml}$ of ethanol added to the prepared solution under magnetic stirrer. The temperature of heater was set at $450{ }^{\circ} \mathrm{C}$ and the prepared solution was sprayed to the glass substrate. The prepared film was annealed at $570{ }^{\circ} \mathrm{C}$ in air for 1 hour.

The diffraction pattern of the $\mathrm{TiO}_{2}$ thin film was investigated by using Philips X'Pert PRO. The morphological properties of the produced film were examined using ZEISS EVO LS10 scanning electron microscope, and the optical properties of the prepared films were studied using Shimadzu UV-1800 UV-VIS spectrophotometer. In photocatalytic measurements, a $300 \mathrm{~W}$ solar simulator (LuzchemPhotoreactor) was used.

The photocatalytic performance of the synthesized film was investigated. Methyl blue (5 ppm) and malachite green $(2 \mathrm{ppm})$ were used for dye degradation in $20 \mathrm{ml}$ solution into a petri dish under continuous stirring by the help of magnetic stirrer. Ciprofloxacin $(5 \mathrm{ppm})$ was used for antibiotic degradation. Two $\mathrm{TiO}_{2}$ thin films were used in all experiments. The first film was used for photocatalytic degradation of dyes and the other one was used in the antibiotic degradation experiment and reusability test. In all test prepared solutions keep in dark for 40 min to achieve absorptiondesorption equilibrium. The antibiotic degradation experiment was repeated 4 times and for each test the solution only changed with freshly prepared ones and the same film was used.

\section{Results and discussion}

The XRD results of the $\mathrm{TiO}_{2}$ thin film obtained with the spray pyrolysis technique at $450{ }^{\circ} \mathrm{C}$ substrate temperature are shown in Figure 1. In the XRD graph, especially $2 \theta$ peaks (101) and (004) were prominently observed. From these results, it can be explained that the thin film has a tetragonal structure and its anatase form. It also complies with Reference code: 96-101-0943. From similar studies, Hosseinzadeh et al. used titanium (IV) butoxide as a titanium oxide source and found similar XRD results with films obtained with Ultrasonicassisted spray pyrolysis technique [22]. Moreover, there are titanium oxide thin films that Dundar et al. obtained with similar structures [23].

The SEM image of the titanium oxide thin film is shown in Figure 2. As can be seen in the figure, although there are roughnesses at some points, it is generally smooth and well sticks to the glass. The transmittance spectrum of the $\mathrm{TiO}_{2}$ film is shown in Figure 3a. It has been observed that the optical transmittance of the film decreases with a decrease in wavelength. The optical absorption method was used to determine the bandgap of produced thin film. The bandgap of the material by the absorption method was obtained by using the Tauc plot. In Figure 3b, the bandgap values of the $\mathrm{TiO}_{2}$ film was found to be approximately $3.33 \mathrm{eV}$. The calculated bandgap value of $\mathrm{TiO}_{2}$ thin film is suitable with literatures [24-25].

The photocatalytic performance of the synthesized $\mathrm{TiO}_{2}$ thin film was investigated through degradation of methyl blue, malachite green dyes and ciprofloxacin antibiotic under solar light simulator. The absorbance of MB for different reaction times is given in Figure 4.

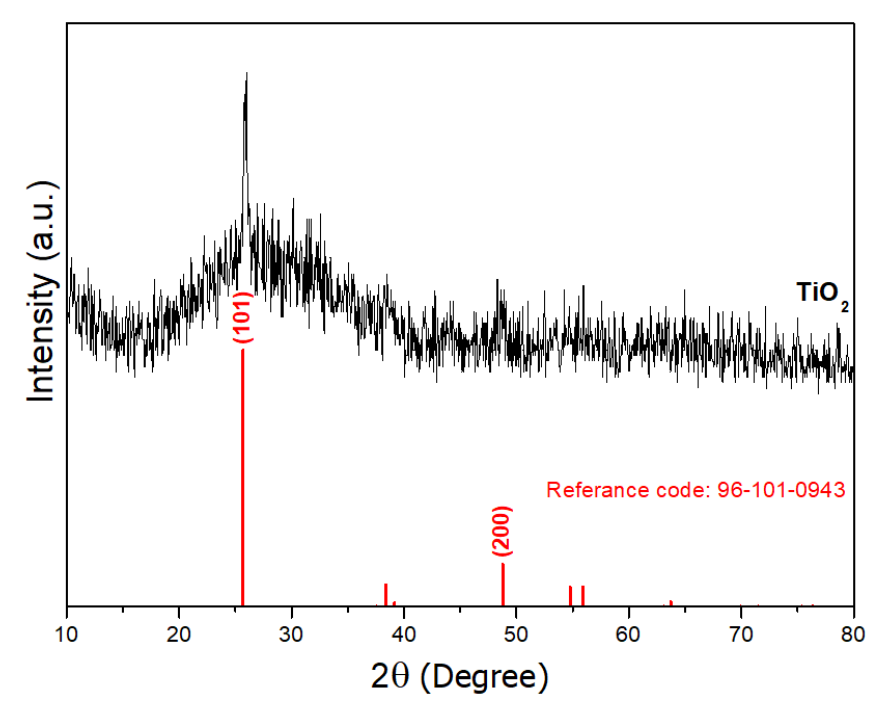

Fig. 1. XRD patterns of $\mathrm{TiO}_{2}$ thin film. 


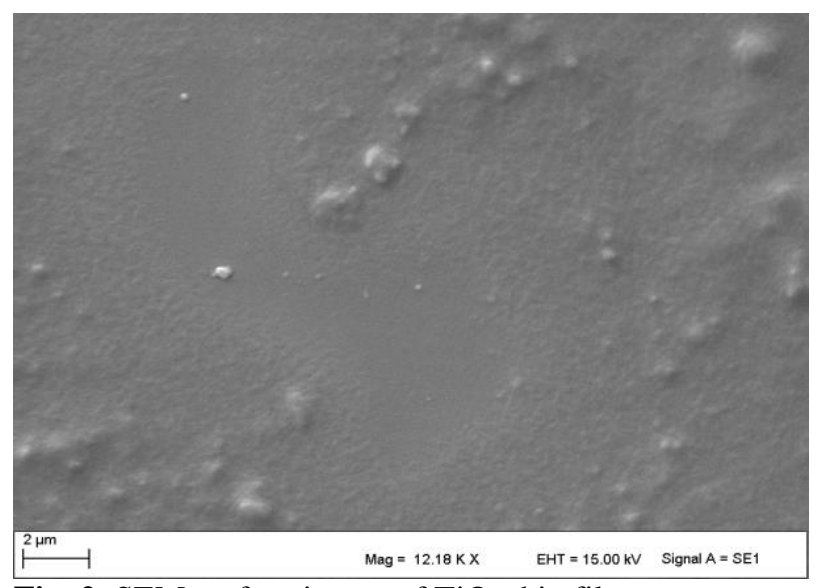

Fig. 2. SEM surface image of $\mathrm{TiO}_{2}$ thin film.

The reference peak for methyl blue (MB) closed to 600 $\mathrm{nm}$ was selected and as is demonstrated in the figure, this peak gradually decreased with increasing reaction time. The experiment was performed $60 \mathrm{~min}$ and after this time, degradation efficiency was reached to $65.52 \%$. The degradation efficiency of $\mathrm{MB}$ as a function of reaction time is given in Figure 4 inset. The degradation efficiency $\eta$ of the thin film was measured using the following equation:

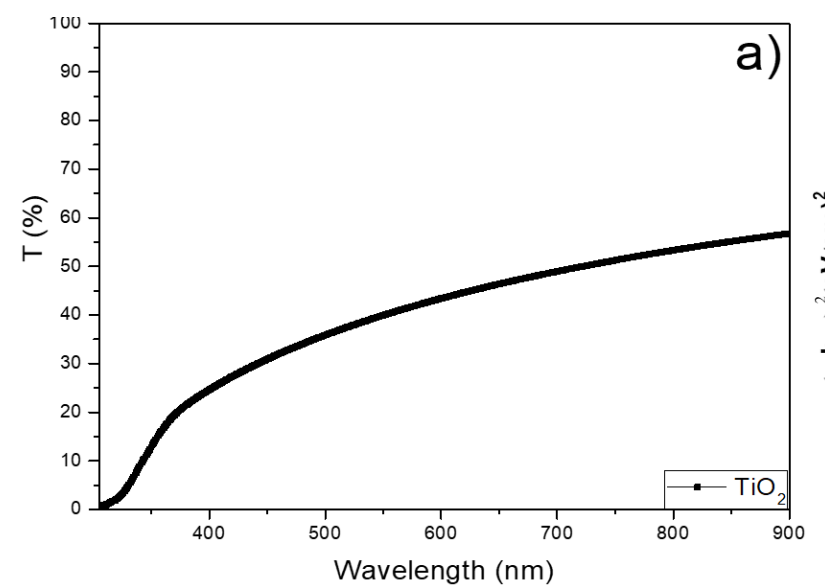

$$
\eta=\frac{\left(C_{0}-C\right)}{C_{0}} \times 100
$$

where $C_{O}$ and $\mathrm{C}$ are the initial concentration and concentration at the sampling time respectively. The photocatalytic performance of $2 \mathrm{ppm}$ malachite green aqueous solution dye was investigated and before the experiment, synthesized thin film, which was used in MB dye degradation cleaning with double distilled water and dried in an oven at $40{ }^{\circ} \mathrm{C}$ for 24 hours. The absorbance spectra of malachite green dye as a function of the reaction time is given in Figure 5. The reference peak was around $619 \mathrm{~nm}$ and the decrease in this peak was used for evaluation photocatalytic degradation efficiency. The degradation efficiency of malachite green dye is given in Figure 5 inset. After 100 min reaction under solar simulator, about $86 \%$ malachite green dye was degraded.

The self-degradation of malachite green was also studied. The absorbance spectra of only malachite green dye without thin film under solar simulator are given in Figure 6. As seen from this figure, after $100 \mathrm{~min}$ irradiation of solar simulator, the absorption peak of malachite green was decreased. $23.5 \%$ malachite green dye was self-degraded under solar simulator. This result also verified that synthesized $\mathrm{TiO}_{2}$ thin film was an effective catalyst for the degradation of malachite green dye

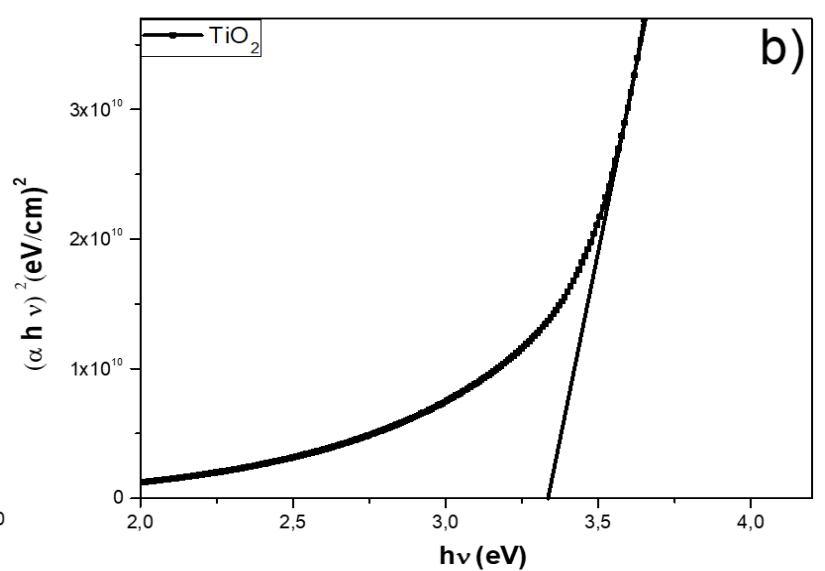

Fig. 3. (a) Transmittance, (b) the optical bandgap (Eg) of $\mathrm{TiO}_{2}$ thin film.

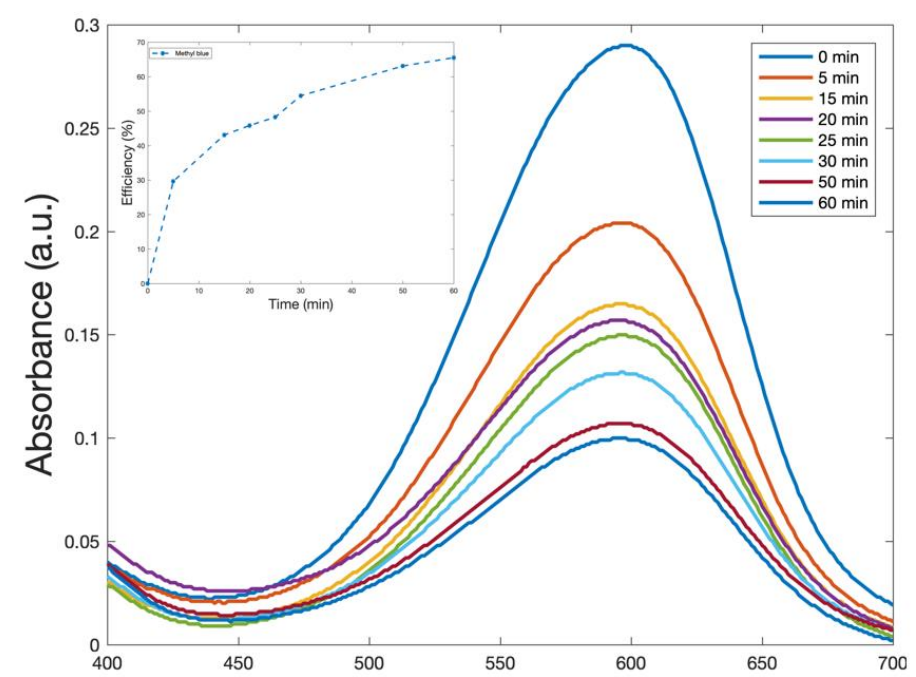

Fig. 4. The photocatalytic performance of $\mathrm{MB}$ dye under solar simulator with $\mathrm{TiO}_{2}$ thin film, inset degradation efficiency $\mathrm{TiO}_{2}$ thin film. 
Synthesis of Titanium Oxide thin Films by Spray Pyrolysis Method...

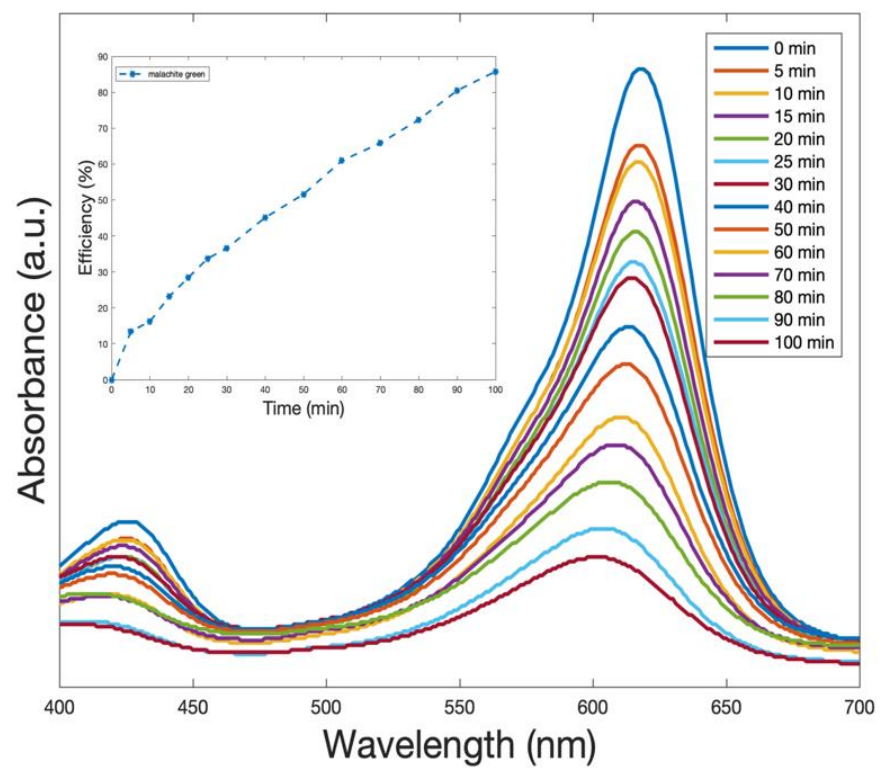

Fig. 5. The photocatalytic performance of malachite green dye under solar simulator with $\mathrm{TiO}_{2}$ thin film, inset degradation efficiency $\mathrm{TiO}_{2}$ thin film.

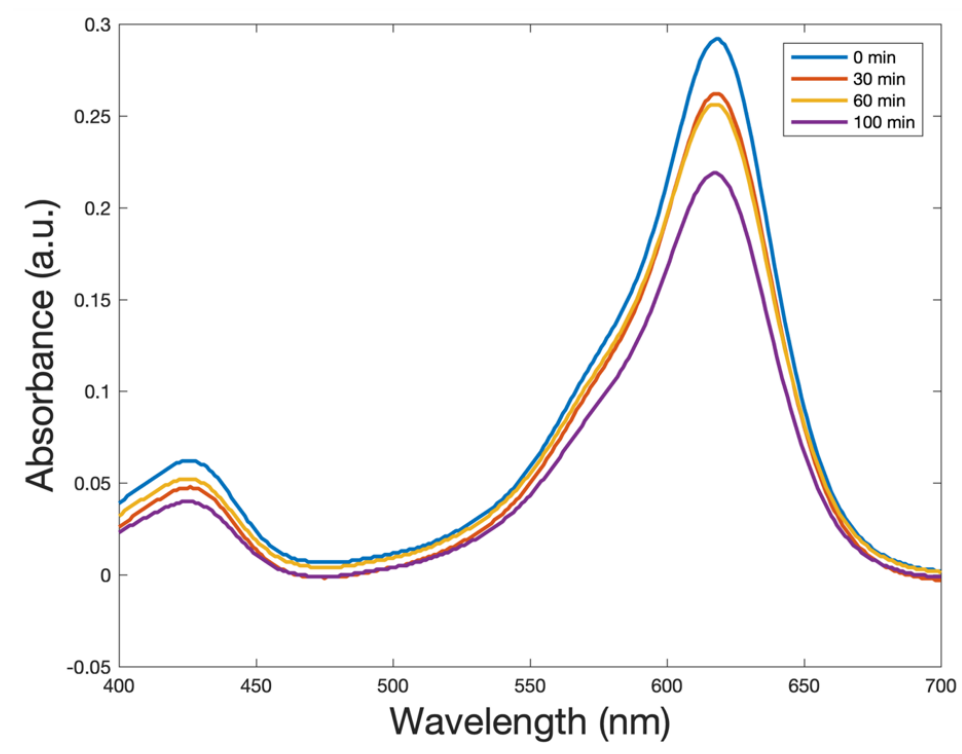

Fig. 6. The self-degradation of malachite green dye under solar simulator as a function of reaction time.

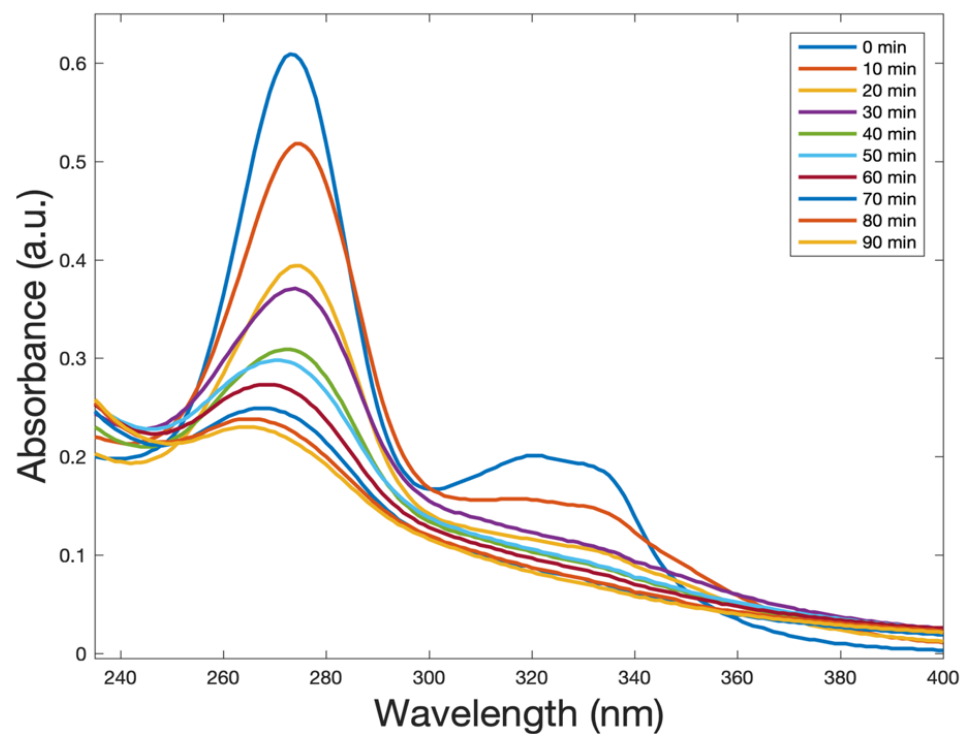

Fig. 7. The absorption spectra of CIP in the presence of $\mathrm{TiO}_{2}$ thin film. 


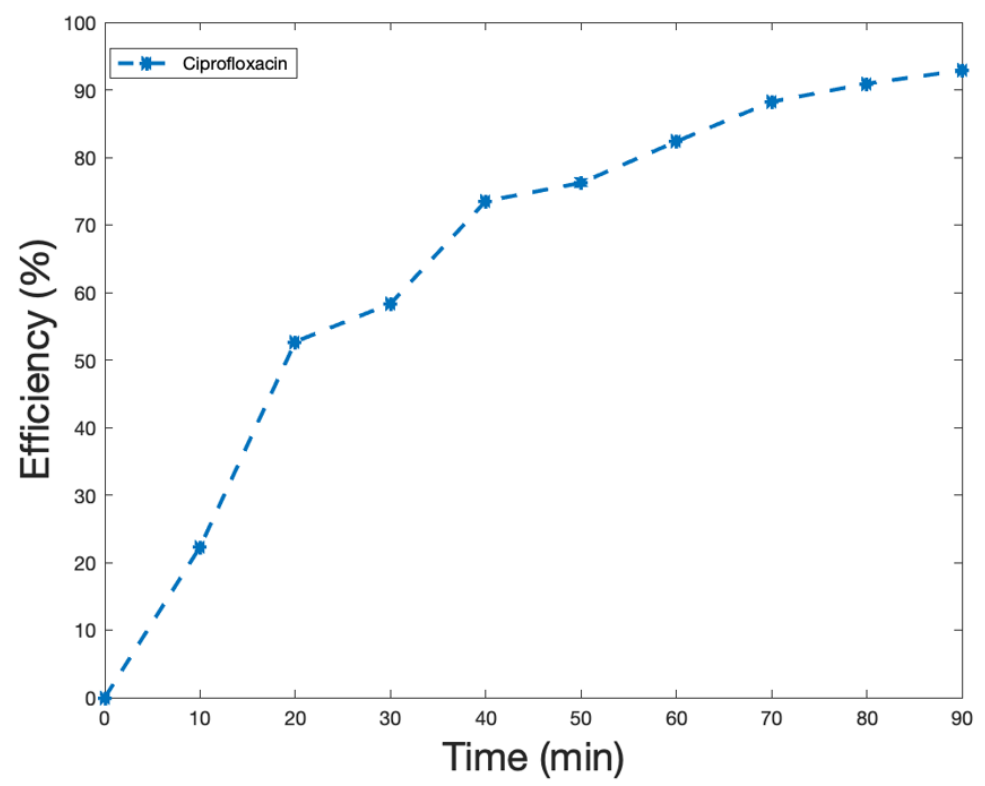

Fig. 8. The photocatalytic degradation of CIP with $\mathrm{TiO}_{2}$ thin film as a function of reaction time.

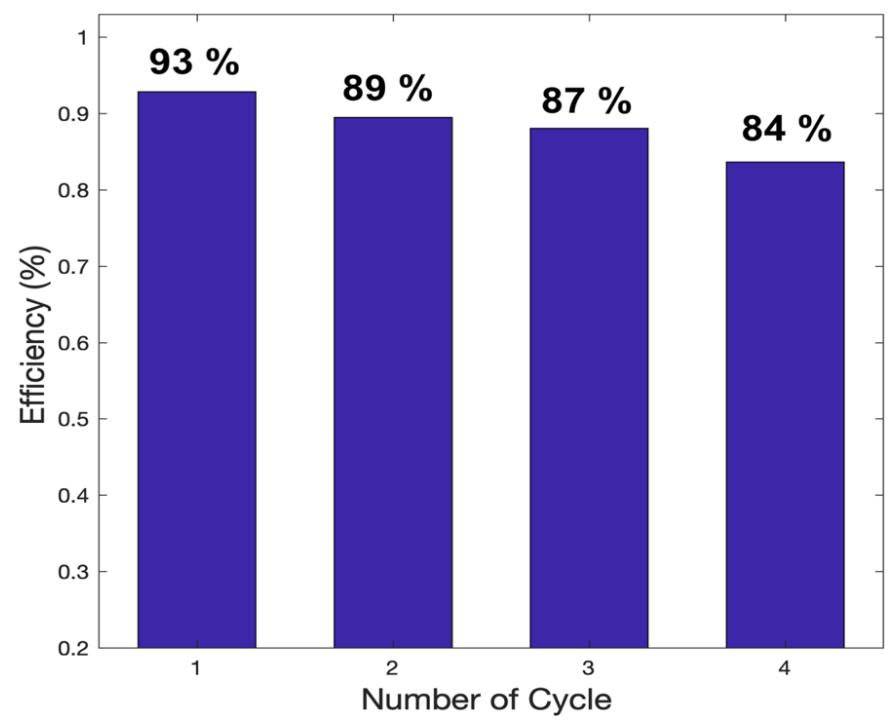

Fig. 9. The reusability of the $\mathrm{TiO}_{2}$ thin film.

The other synthesized $\mathrm{TiO}_{2}$ thin film was used for the CIP experiment. The concentration of CIP is chosen as 5 ppm, (commonly used standards as the photocatalytic experiment that is conducting with thin films) and $20 \mathrm{ml}$ aqueous solution was used. The absorption spectra of CIP with $\mathrm{TiO}_{2}$ thin film under solar light simulator are demonstrated in Figure 7. The reference peak of CIP was selected around $273 \mathrm{~nm}$ and the decrease of this peak as a function of reaction time is apparently seen from the figure. The peak position of CIP moves to lower wavelength, i.e. blueshift is observed with increasing reaction time and after $90 \mathrm{~min}$ irradiation, the wavelength of peak move to $265 \mathrm{~nm}$. This blueshift was associated with the aromatic ring opening process [26-27]. At the first stage of the experiment, $\mathrm{TiO}_{2}$ thin film and CIP left in dark for $40 \mathrm{~min}$ for providing absorption-desorption equilibrium. The photocatalytic degradation efficiency of $\mathrm{TiO}_{2}$ thin film with CIP antibiotic is demonstrated in Figure 8. The photocatalytic efficiency of $\mathrm{TiO}_{2}$ thin film has significantly enhanced when compared to malachite green dye. Although the photocatalytic reaction time of malachite green dye is longer than CIP, the removal rate of CIP is higher than the malachite green dye. The removal rate of malachite green dye was reached to $86 \%$ with 100 min irradiation, but the removal rate of CIP was reached to $93 \%$ with 90 min irradiation.

The photocatalytic stability and reusability is an essential parameter for industrial applications, and photocatalytic stability of the synthesized $\mathrm{TiO}_{2}$ thin film was studied. The recycling experiments are conducted under a solar light simulator for four cycles with the same condition of the experiment. After each cycle, $\mathrm{TiO}_{2}$ thin film was washed with distilled water and dried at oven at $40{ }^{\circ} \mathrm{C}$ for 24 hours. As seen in Figure 9 the stability of $\mathrm{TiO}_{2}$ thin film did not decrease significantly after four-cycle. These results implied that the synthesized $\mathrm{TiO}_{2}$ thin film posses excellent cycle stability. A recent study related to the reusability of boron and cerium doped $\mathrm{TiO}_{2}$ catalysts demonstrates that photocatalytic degradation of CIP is decreased from 93 
$\%$ to $69 \%$ at the end of the fifth cycle [28]. The photoactivity of $\mathrm{TiO}_{2}$ thin film ascribed by the illustrated solar light irradiation might generate electron-hole pairs that can react with water to produce hydroxyl and superoxide radicals, and they can oxidize and mineralize the CIP molecules [29].

\section{Conclusion}

In this study, $\mathrm{TiO}_{2}$ thin film was successfully synthesized by spray pyrolysis methods on glass substrate. The synthesized film was characterized by using several analytical instruments. It was determined by XRD measurements that $\mathrm{TiO}_{2}$ thin film was in anatase form. Bandgap of the obtained film was found to be $3.33 \mathrm{eV}$. The photocatalytic effect of this film on dyestuffs and antibiotics was investigated. As a result of the experiments, it was found that methyl blue degradation was approximately $65 \%$ after 90 minutes, malachite green degradation was $86 \%$ after 100 minutes, and antibiotic degradation was $93 \%$ after 90 minutes. Degradation experiments on ciprofloxacin were carried out using the same film for 4 times and it was found that the effect of photocatalytic degradation decreased by $9 \%$ at the end of 4 experiments. From here it is understood that the photocatalytic degradation reusability of titanium thin films is quite high.

Kerli S. -PhD in physics, Associate Professor in Energy Systems Engineering;

Eskalen H. -PhD in Material Science and Engineering, Assistant Professor in the Vocational School of Health Services.

[1] F. Meng, M. Song, B. Song, Y. Wei, Q. Cao, \& Y. Cao, Chemosphere 243, 125322 (2020) (https://doi.org/10.1016/j.chemosphere.2019.125322).

[2] J. Li, Z. Chen, J. Fang, Q. Yang, X. Yang, W. Zhao, D. Zhou, X. Qian, C. Liu, \& J. Shao, Materials Express 9, 437 (2019) (https://doi.org/10.1166/mex.2019.1522).

[3] M.C. and M.G. Hasan Eskalen, Celal Kursun, Mikail Aslan, H. Eskalen, C. Kursun, M. Aslan, M. Cesme, \& M. Gogebakan, arXiv preprint arXiv:1709.06941, 92093, 1 (2017).

[4] Barbara Ambrosetti, Luigi Campanella, \& Raffaella Palmisano, Journal of Environmental Science and Engineering A, 4, 273 (2015) (https://doi.org/10.17265/2162-5298/2015.06.001).

[5] H. Guo, N. Jiang, H. Wang, N. Lu, K. Shang, J. Li, \& Y. Wu, Journal of Hazardous Materials 371, 666 (2019) (https://doi.org/10.1016/j.jhazmat.2019.03.051).

[6] K. Yi, D. Wang, QiYang, X. Li, H. Chen, J. Sun, H. An, L. Wang, Y. Deng, J. Liu, \& G. Zeng, Science of the Total Environment, 605-606, 368 (2017) (https://doi.org/10.1016/j.scitotenv.2017.06.215).

[7] V.V. Kondalkar, S.S. Mali, R.M. Mane, P.B. Dandge, S. Choudhury, C.K. Hong, P.S. Patil, S.R. Patil, J.H. Kim, \& P.N. Bhosale, Industrial and Engineering Chemistry Research 53, 18152 (2014) (https://doi.org/10.1021/ie501821a).

[8] F. Wang, X. Yu, M. Ge, \& S. Wu, Chemical Engineering Journal 384, 2 (2020) (https://doi.org/10.1016/j.cej.2019.123381).

[9] C. Kursun, M. Gogebakan, H. Eskalen, S. Uruş, \& J. H. Perepezko, Journal of Inorganic and Organometallic Polymers and Materials 30, 494 (2020) (https://doi.org/10.1007/s10904-019-01209-w).

[10] H. Eskalen, S. Uruş, H. Yaykaşlı, \& M. Gögebakan, Microstructural Characterization of Ball Milled Co 60 Fe 18 Ti 18 Nb 4 Alloys and Their Photocatalytic Performance. Alloy Mater. Their Allied Appl. (Wiley, 2020), pp. 91 (https://doi.org/10.1002/9781119654919.ch6).

[11] S. Kerli, Ü. Alver, H. Eskalen, \& A. K. Soğuksu, ComptesRendus de L'AcademieBulgare des Sciences 72 , 327 (2019) (https://doi.org/10.7546/CRABS.2019.03.06).

[12] S. Kerli, Ü. Alver, H. Eskalen, S. Uruş, \& A. K. Soğuksu, Russian Journal of Applied Chemistry 92, 304 (2019) (https://doi.org/10.1134/S1070427219020216).

[13] S. Kerli\& A.K. Soğuksu, Zeitschriftfür Kristallographie-Crystalline Materials 234, 725 (2019) (https://doi.org/10.1515/zkri-2019-0043)

[14] S. Kerli, A.K. Soğuksu, \& M. Kavgac1, International Journal of Modern Physics B, 34, 2050081 (2020) (https://doi.org/10.1142/S0217979220500812).

[15] R. Ayouchi, C. Casteleiro, R. Schwarz, J. R. Barrado, \& F. Martín, Physica Status Solidi (C) Current Topics in Solid State Physics 7, 933 (2010) (https://doi.org/10.1002/pssc.200982895).

[16] S. Kerli, Ö. Akgül, Ü. Alver, AIP Conf. Proc., AIP Publishing LLC, 280002 (2016) (https://doi.org/10.1063/1.4944281).

[17] M.S.P. Sarah, M.Z. Musa, M.N. Asiah, \& M. Rusop, 2010 International Conference on Electronic Devices, $\begin{array}{llllll}\text { Systems and Applications, ICEDSA } 2010 \quad-\quad \text { Proceedings } & 361 & \text { (2010) }\end{array}$ (https://doi.org/10.1109/ICEDSA.2010.5503040).

[18] S. Sebnem Cetin, S. Corekci, M. Cakmak, \& S. Ozcelik, Crystal Research and Technology 46, 1207 (2011) (https://doi.org/10.1002/crat.201100195).

[19] T. Touam, M. Atoui, I. Hadjoub, A. Chelouche, B. Boudine, A. Fischer, A. Boudrioua, \& A. Doghmane, EPJ Applied Physics, 67, (2014) (https://doi.org/10.1051/epjap/2014140228). 
[20] A. Ranjitha, N. Muthukumarasamy, M. Thambidurai, R. Balasundaraprabhu, \& S. Agilan, Optik 124, 6201 (2013) (https://doi.org/10.1016/j.ijleo.2013.04.085).

[21] S.T. Sundari, N.C. Raut, T. Mathews, P.K. Ajikumar, S. Dash, A.K. Tyagi, \& B. Raj, Applied Surface Science 257, 7399 (2011) (https://doi.org/10.1016/j.apsusc.2011.02.064).

[22] G. Hosseinzadeh, H. Rasoulnezhad, N. Ghasemian, \& R. Hosseinzadeh, Journal of the Australian Ceramic Society 55, 387 (2019) (https://doi.org/10.1007/s41779-018-0246-8)

[23] I. Dundar, M. Krichevskaya, A. Katerski, \& I. O. Acik, Royal Society open science 6, 181578 (2019) (https://doi.org/10.1098/rsos.181578)

[24] K.B. Chaudhari, Y.N. Rane, D.A. Shende, N.M. Gosavi, \& S.R. Gosavi, Optik 193, 163006 (2019) (https://doi.org/10.1016/j.ijleo.2019.163006).

[25] D. Komaraiah, E. Radha, M.V.R. Reddy, J.S. Kumar, \& R. Sayanna, i-Manager's Journal on Material Science 7, 28 (2019) (https://doi.org/10.26634/jms.7.1.15719)

[26] C. Zou, M. Liang, Z. Yang, X. Zhou, Y. Yang, \& S. Yang, Nanotechnology 31, 345604 (2020) (https://doi.org/10.1088/1361-6528/ab912f).

[27] M. Chen \& W. Chu, Industrial \& engineering chemistry research 51, 4887 (2012) (https://doi.org/10.1021/ie300146h)

[28] M. Manasa, P.R. Chandewar, \& H. Mahalingam, Catalysis Today (https://doi.org/10.1016/j.cattod.2020.03.018).

[29] C. Yang, W. Dong, G. Cui, Y. Zhao, X. Shi, X. Xia, B. Tang, \& W. Wang, Scientific Reports 7, 1 (2017) (https://doi.org/10.1038/s41598-017-04398-X).

\author{
С. Керлі, Х. Ескален
}

\title{
Синтез тонких плівок оксиду титану методом розпилювального піролізу та його фотокаталітична активність для розкладання барвників та ципрофлоксацину
}

\footnotetext{
${ }^{1}$ Університет Кахраманмарас Iстікляль, Кахраманмарас, Туреччина, suleymankerli@yahoo.com; ${ }^{2}$ Професійно-технічна школа медичних служб, Департамент медичних послуг та техніки, програма оптики, Університет Кахраманмарас Сютчу Імам, Кахраманмарас, Туреччина,

${ }^{3}$ Університет Зумчу Імам, Кахраманмарас, Туреччина
}

\begin{abstract}
Тонкі плівки оксиду титану $\left(\mathrm{TiO}_{2}\right)$ отримано методом розпилювального піролізу. Структурні властивості отриманих плівок досліджували за допомогою дифракції X-променів (XRD) та встановлено наявність тетрагональної структури. Морфологічні особливості досліджували за допомогою скануючої електронної мікроскопії (SEM). Крім того, досліджено оптичні властивості плівки та розраховано ширину забороненої зони. Досліджено фотокаталітичні властивості тонкої плівки $\mathrm{TiO}_{2}$ на барвник та антибіотик. У тесті розкладання барвника тонкої плівки використано метиловий синій та малахітовий зелений. Зокрема, було виявлено високу деградацію $86 \%$ через 100 хвилин на малахітовому зеленому. Більше того, деградація ципрофлоксацину через 90 хвилин виявилася $93 \%$. Досліджено антибіотик ципрофлоксацину та встановлено, що синтезована тонка плівка $\mathrm{TiO}_{2}$ має чудову стабільність.
\end{abstract}

Ключові слова: $\mathrm{TiO}_{2}$, метиловий синій, малахітовий зелений, ципрофлоксацин. 